To link to this article / Para enlazar con este artículo:

https://doi.org/10.14198/fem.2020.35.07

To cite this article / Para citar este artículo:

Steinpórsdóttir, Finnborg Salome y Einarsdóttir, Porgerður. «Jumpstart, potentials and hindrances: collaboration projects in gender mainstreaming and gender budgeting». En Feminismo/s, 35 (junio 2020): 179-205. Monographic dossier / Dossier monográfico: A critical practice of thinking otherwise: Bacchi, Gender and Public Policy Analysis, coord. Angela O'Hagan, DOI: 10.14198/fem.2020.35.07

\title{
JUMPSTART, POTENTIALS AND HINDRANCES: \\ COLLABORATION PROJECTS IN GENDER MAINSTREAMING AND GENDER BUDGETING
}

\section{ESTÍMULO, POTENCIALES Y OBSTÁCULOS: PROYECTOS DE COLABORACIÓN EN TRANSVERSALIDAD Y PRESUPUESTOS CON ENFOQUE DE GÉNERO}

\author{
Finnborg Salome STEINPÓRSDÓTTIR \\ University of Iceland, Reykjavík \\ finnborg@hi.is \\ orcid.org/0000-0001-9581-0310 \\ Porgerður EINARSDÓTTIR \\ University of Iceland, Reykjavík \\ the@hi.is \\ orcid.org/0000-0001-8906-0760
}

\begin{abstract}
Many European organisations have committed to and formally adopted gender mainstreaming and gender budgeting strategies; however, their implementation has not been as effective as anticipated. The Department of Gender Studies at the University of Iceland has been collaborating with public sector organisations in Iceland, a City and a University, to advance implementation of these strategies. The collaboration entails post-graduate students analysing the problem representation and gendering of public activities and providing policy actors with research-informed advice on how to integrate a gender perspective in their management procedures and processes. Drawing on interview data with the policy actors involved in the collaboration projects, we found organisational noncommitment to gender mainstreaming and gender
\end{abstract}

Los contenidos de la revista se publican bajo una licencia de Creative Commons Reconocimiento 4.0 Internacional (CC BY 4.0)

Feminismo/s 35, junio 2020, pp. 179-205 
budgeting, lack of knowledge about these issues and a superficial approach to implementing the strategies. Based on the findings, we explored the potential explanations and the hindrances related to using collaboration projects to jumpstart structural transformative gender+ equality work.

Keywords: Gender budgeting; Gender mainstreaming; Public policy; Jumpstart; Structural transformation.

\section{Resumen}

Muchas organizaciones europeas se han comprometido y adoptado formalmente la transversalidad de género y los presupuestos con enfoque de género; sin embargo, la implementación de las estrategias no ha sido tan efectiva como se había anticipado. El Departamento de Estudios de Género de la Universidad de Islandia ha estado colaborando con organizaciones del sector público, una ciudad y una universidad, para avanzar en la implementación de estas estrategias. La colaboración implica que el alumnado de postgrado realiza análisis de actividades públicas desde la perspectiva de género e identifica oportunidades para integrar la perspectiva y reformar los procedimientos y procesos para avanzar en la construcción de la igualdad. A partir de datos de entrevistas con actores políticos involucrados en los proyectos de colaboración, hemos encontrado ausencia de compromiso organizativo con la transversalidad de género y los presupuestos con enfoque de género, falta de sensibilidad de relaciones de género y enfoque superficial en la implementación de las estrategias. Los resultados del estudio nos han dado la oportunidad de explorar las posibilidades y los obstáculos en el uso de proyectos de colaboración para estimular el trabajo de transformación estructural en igualdad de género.

Palabras clave: presupuestos con enfoque de género; transversalidad de género; políticas públicas; estímulo; transformación estructural.

\section{INTRODUCTION}

Today, in many European countries, public institutions have adopted gender mainstreaming and gender budgeting. However, implementation has not been as effective as desired (Bendl and Schmidt 375; Bacchi and Eveline, «Mainstreaming» 52; O'Hagan and Klatzer 7; Scala and Paterson 208; Sharp and Broomhill 21). Because the efficiency of gender mainstreaming is contested (Bacchi and Eveline, «Mainstreaming» 53; Eveline and Todd 544), our interest is in providing knowledge about the institutional, attitudinal and 
conceptual constraints for the successful implementation of gender mainstreaming and gender budgeting. In particular, we examine how policy actors interpret and respond to gender mainstreaming and gender budgeting obligations in their day-to-day work, an aspect that has not received much attention in the literature on the implementation gap (Scala and Paterson 209).

This article draws on semi-structured interview data with policy actors from public sector organisations, the City of Reykjavík (hereafter the City) and the University of Iceland (hereafter the University), that are obliged by Icelandic law and regulations to implement gender mainstreaming (Act on the Equal Status and Equal Rights of Women and Men no. 10/2008). Iceland has a reputation as an international frontrunner in gender equality (World Economic Forum 6). However, its portrayal as a gender paradise has been contested (Einarsdóttir 1-2) and the country is trapped in the paradox of «strong equality policy, weak practice» (Johnson, Einarsdóttir and Pétursdóttir 175). In other words, extensive formal acceptance and adoption of gender equality measures, but only «partial and variable institutionalization in terms of impact on institutional practices, norms, and outcomes» (Mackay, Monro and Waylen 254-255). Scala and Paterson (228) include gender analysts in their research on the micro-levels of implementation. As the Icelandic legislation taking a "change everything by everyone» (Benschop and Verloo 284) approach, it is particularly meaningful to examine how regular policy actors at different levels engage with gender and enact those obligations in their work.

At the policy level, the organisations included in this analysis demonstrate a commitment by formally adopting gender mainstreaming and gender budgeting strategies to facilitate gender equality (Háskóli Íslands, University of Iceland Equality Action Plan; Reykjavíkurborg, Kynjajafnrétti; Reykjavíkurborg, Mannréttindi; Steinpórsdóttir et al. 182-183). They have instituted gender equality infrastructures, such as equality and diversity departments, taskforces and coordinators (Háskóli Íslands, Equality and diversity; Reykjavíkurborg, Human Rights Office). Moreover, in order to take steps towards implementing gender mainstreaming and gender budgeting measures, the organisations have been collaborating with the Department of Gender Studies at the University since 2005 (Einarsdóttir and Pétursdóttir 18). This has been done in the belief 
that if the scholarly community collaborates with organisations together they «can jumpstart progress toward gender equality» (Correll 745).

The collaboration, which was initiated by the Gender Studies programme at the University, is based on the idea that the connection between research and action (Eveline and Todd 551-554) and the critical engagement of external actors (Sharp and Broomhill 8) can facilitate implementation. The collaboration entails the jumpstart of structural transformative gender equality work in which post-graduate students take on real, practical projects from policy actors under the supervision of gender experts, i.e. teachers. In the projects, the students use Bacchi's (2) critical analytical strategy, «what's the problem represented to be?» (WPR), to assess the problem representation and the gendering of certain activities (e.g. policies, resource distribution), and they provide research-informed advice on how to integrate a gender perspective into the management procedures and processes to ensure more gender equitable outcomes. In recent years, a growing number of students have approached their projects with a gender+ perspective. In doing so, they are «recognising that gender inequality and other inequalities are connected and are thus best addressed with those intersections in mind» (Verloo et al. 27). This is in line with increased efforts to incorporate different social and power relations into gender mainstreaming and gender budgeting practices, such as the GBA+ approach in Canada (Her Majesty the Queen in Right of Canada 1), and addresses previous criticisms of the strategies for not including intersectionality (Benschop and Verloo 284).

The collaborative projects addressed three categories of issues across public services: range and design of public service; organisational management and internal processes; public facing communication and information on services. The first category on services provided (by the City and the University) included a range of service provision: recreational centres, services for senior citizens, programmes for museum events and exhibitions, course catalogues, student psychological services, student disability services, student exchange programmes, and lastly, fees and charging policy for services and activities, e.g. children's participation in sports. The second category consists of organisational issues (in the University), including internal grants, the working conditions of, for example, PhD students, and academic housework (Heijstra et al. 211), student supervision and committee work. The third 
category consists of public relations (in the City and the University), such as accessibility to information about the services provided, news produced by the organisations, promotional material and awareness campaigns.

Correll (726) points out that while there has been extensive theoretical and empirical knowledge production on inequalities and how they are reproduced, it has not sufficiently enabled positive change. Furthermore, there is a lack of research on how to change those inequalities effectively, which she believes is because the "changes we can realistically make in any one instance are often small and imperfect» (Correll 726-727). The objective of the collaboration projects was to give the students an opportunity to engage in practical projects that simultaneously contribute to structural transformation and promote gender+ equality. Based on a cursory examination of the course evaluations, in general, the students were satisfied with the projects; however, for the collaborating partners, our intuition and subjective impression was that while the outcome of the projects was the generation of knowledge on gender+ inequalities, the projects did not result in any significant structural change that facilitates equality. Inspired by Correll, the study discussed in this article aimed to more systematically assess how organisations respond to the advancement of gender equality through public policy and legislation; that is, the government's objective to implement gender mainstreaming and gender budgeting, and specifically gain insight into the outcomes of the collaboration projects.

Drawing on semi-structured interviews with policy actors that participated in the collaboration projects, we found an organisational noncommitment to gender mainstreaming and gender budgeting. Moreover, the policy actors have inadequate knowledge about the strategies and their approach to implementing them is superficial. Based on the findings of our analysis, we explore the potential for and hindrances of using collaboration projects to jumpstart structural transformative gender+ equality work. Before elaborating on the study's findings and conclusions, we begin with a review of the literature that backgrounds the study, and then we present the methodology used in our research. 


\section{GENDER MAINSTREAMING AND GENDER BUDGETING}

Gender mainstreaming and gender budgeting are structural transformation strategies that are used to facilitate gender equality. Both strategies are most commonly defined as an integration of gender analysis in all aspects and all stages of the policy-and decision-making process (Council of Europe, Gender 12) and the budgetary process (Council of Europe, Recommendation). This definition has been criticised for being too technocratic (O'Hagan 29). Hence, drawing on Benschop and Verloo (283) and O'Hagan (20-21), we approach gender mainstreaming and gender budgeting as strategies that aim to challenge the supposed gender-neutral policies, programmes and resources that re/produce gender biases and inequalities and change organisational processes to ensure that they promote gender equality. This approach shifts the attention from individuals and their rights, and from comparing stereotypical characteristics of women and men, to the structural dimensions that produce and maintain gender inequalities, such as gendered institutions, systems, policies, processes, norms, expectations, etc. (O'Hagan 20; Benschop and Verloo 283; Bendl and Schmidt 364; Eveline and Todd 537).

In the research context, gender mainstreaming and gender budgeting are perceived to be interrelated. Some feminist scholars and activists have contested the association between the strategies because the application and implementation of gender mainstreaming are not comparable in all respects (O'Hagan 29). O'Hagan argues that gender budgeting goes further than gender mainstreaming, because «gender budgeting activates gender mainstreaming by including gender analysis of revenue and expenditure in all aspects of policy and programmes, and should result in gender-aware proposals across all policy domains» $(31)^{1}$. In the following sections, we discuss several of the shortcomings of and potentials for positive outcomes of gender mainstreaming and gender budgeting, as documented in the application of the strategies within organisations.

1. Original emphasis.

Feminismo/s 35, junio 2020, pp. 179-205 


\section{SHORTCOMINGS OF AND POTENTIALS FOR POSITIVE OUTCOMES}

While gender mainstreaming and gender budgeting are believed to have the potential to facilitate structural change, their implementation has several shortcomings, including, for example an organisation's ineffectiveness in using these strategies to bring about change that promotes equality and how the strategies are approached and applied. In general, feminist researchers have drawn attention to challenges, such as the «strong equality policy, weak practice» paradox (Johnson, Einarsdóttir and Pétursdóttir 175), and that the implementation of gender mainstreaming has been depoliticised. Feminist advocates have been removed from the process, and the strategies have become an overly technical and bureaucratised issue (see e.g. Powell, Ah-King and Hussénius 129; Klatzer, Brait and Schlager 147-151). A depolitisation of gender mainstreaming is manifested in the way in which power relations are ignored. It is further undermined by the prevailing idea that gender equality work should avoid conflict and not be carried out from a feminist perspective, as such a perspective would be seen as «being in opposition to professionalism and legitimate political issues» (Andersson 203). In her research on attitudes towards gender mainstreaming at the local government level in Sweden, Andersson (214-216) finds that discussion on (male) privileges and actions to improve women's position are avoided, which, in turn, weakens the transformative potential of gender mainstreaming. Moreover, it delegitimizes feminist perspectives or the actions of «femocrats», that is «bureaucrats with a feminist agenda» (Woodward 66).

Our study is especially interested in the day-to-day level of implementation. Benschop and Verloo (284) argue that the ambitious goal of «changing everything everywhere by everyone» is risky. By requiring policy actors at all levels to implement these strategies, there is the possibility that the transformative aspect of gender mainstreaming will fail due to the lack of understanding about the strategy, the problem or gender perspectives. In Woodward's (69) opinion the term «mainstreaming» is open for interpretation and «the further away from the femocrat centre, the more frequent the misunderstanding of the term [gender mainstreaming] and its specific connotations». Another 
issue that must be anticipated is the risk that the policy actors will resist the promotion of gender equality (see e.g. Lombardo and Mergaert 307).

The ongoing tendency to dismantle formal gender equality infrastructures further undermines the implementation process, as research shows they are essential for positive outcomes of gender mainstreaming and gender budgeting. However, these infrastructures must have authority and clear responsibilities, competence and resources to initiate, support and monitor the implementation (Klatzer, Brait and Schlager 152; Benschop and Verloo 284-287; Eveline and Todd 551-554). Scala and Paterson's research on local gender analysts enacting gender mainstreaming in Canada reveals how programme cuts and internal reorganisation of government agencies has left gender machineries isolated from the policy making; thus, they are disempowered. To advance gender and diversity work within their organisation, gender analysts have to compromise and appeal to the dominant neoliberal managerial discourses (Scala and Paterson 228-230).

Organisational obligation does not necessarily lead to organisational commitment, especially if the relevance of gender to policies and programmes is questioned within the organisation (Eveline and Bacchi 306-308). To ensure commitment among policy actors, and overcome the idea of the irrelevancy of gender, Eveline and Bacchi (306-308) suggest collaborative research projects, where internal policy actors gain hands-on experience with gender analysis to ensure long-term learning and commitment by organisations. Such collaboration is in line with Sharp and Broomhill's (8) arguments that without the critical engagement of external actors, gender budgeting efforts might not be effective. Moreover, such collaboration contributes to the accountability of the organisation.

Correll (735-737) argues for a «small wins» model of change in order to encourage action to facilitate equality, and believes it can enable larger organisational transformation. However, Bacchi and Eveline (Approaches 131) warn against the 'project trap', that is, when we are only generating knowledge on how gender inequality is produced and maintained in a narrow context instead of taking a broader approach toward examining the social organisational contexts (Bacchi and Eveline, Mainstreaming 52). To break out of the project trap, they suggest that the starting point of gender analysis is problematisations and the application of Bacchi's (2) WPR critical analytical strategy.

Feminismo/s 35, junio 2020, pp. 179-205 
WPR acknowledges that the policies, and how the problem is represented in them, can shape and produce social and power relations, including gender relations; therefore, they are gendering, that is, they (re)produce gender as a relation of inequality (Bacchi and Eveline, «Approaches» 131). Genderneutral policy and decision-making that does not recognise men's and women's different social positions and conditions will reproduce gendered power relations and male bias, resulting in gendered processes and outcomes (Bacchi and Eveline, «Mainstreaming» 52; O'Hagan and Klatzer 5). This also applies to other social and power relations; hence, policies can be heteronorming, racialising, classing and (dis)abling (Bacchi and Eveline, «Approaches» 112).

In the collaboration between the Department of Gender Studies, the City and the University, researchers aimed to put into practice the recommendations presented in the literature to encourage positive outcomes of gender mainstreaming and gender budgeting. The following section discusses the methodology and semi-structured interview data used in this study, before addressing the potentials for and hindrances of using collaboration projects to jumpstart structural transformative gender+ equality work.

\section{METHODOLOGY}

This research is part of a feminist transformative project that aims to find ways to progress gender+ equality within the City of Reykjavík and the University of Iceland. To assess the collaboration and determine the extent to which it achieved its objectives, the paper draws on semi-structured interview data with policy actors from the City and the University that participated in the collaboration projects with the Department of Gender Studies at the University from 2016 to 2018. The data were collected in October and November 2018. The aim of the interviews was twofold. First, we aimed to gain insight into how organisations respond to public policy and legislation (in this case, the government's objective to implement gender mainstreaming put forward in the Act on the Equal Status and Equal Rights of Women and Men No. 10/2008), and if policy actors at different levels embrace or reject the responsibility of doing this work. The interview frame was designed to gain insights using the following questions: How do the policy actors understand their responsibilities regarding equality work? How do they 
understand gender mainstreaming and/or gender budgeting? Is feminism present or excluded in their understanding of the strategy? Or is there any conflict relating to that? Second, we aimed to gain insight into the status of the implementation of gender mainstreaming in relation to the collaboration projects and the jumpstart it aimed to initiate. The questions that guided this part were: What do the policy actors take from these learning exercises? Has it impacted how they approach gender mainstreaming in their everyday work? Do the policy actors implement the suggested measures? If not, why not? Have the projects resulted in «spill-over effects»; in other words, has the gender perspective been integrated into other activities? If not, then why not?

To select the participants, the collaboration projects that were completed from 2016 to 2018 were mapped, including information on the project's creator, the participating policy actors from the collaborating organisation and the teacher's grade of the project (in order to assess its quality). In total 33 collaboration projects were completed in that period, with the participation of 17 policy actors from those organisations. The interviewees were selected based on the following criteria: a) the policy actor's position within the organisation (we wanted to interview people that still work within the same division as the policy area); b) the idea of the project originated with the policy actors, their division or the equality machinery of their organisations (not the teachers); and c) the quality of the project (the poorest projects were excluded). Although the initiative for the projects came from the policy actors or their organisations, some of the students still encountered resistances, such as the lack of access to information and data and being disregarded by the policy actors. The supervision by the teachers consisted of responding to these hindrances by guiding the students in finding relevant information and data from other sources and supporting them in dealing with the policy actors. The students were encouraged to consider the lack of information as data that they could use as part of their research-informed advice on how the policy makers could advance the implementation of gender mainstreaming and gender budgeting. This pushed the students to be resourceful and to think creatively. While encountering and dealing with resistance can be challenging, it is a valuable part of the students' learning process, as gender equality experts frequently have to deal with these types of issues in their work (Lombardo and Mergaert 307; Andersson 203; Scala and Paterson 230).

Feminismo/s 35, junio 2020, pp. 179-205 
Semi-structured interviews were conducted with 11 policy actors, six from the University and five from the City. Nine women and two men were interviewed, reflecting the frequent gender imbalance among policy actors that take on gender+ equality work (see e.g. Eveline and Bacchi 307). The position of the policy actors in the management structures was classified into two groups at two levels. Six of the participants are management policy actors, a position that includes management directors, head of divisions and deans. Five of the participants are mid-level policy actors (project managers and managers), and one is a gender policy actor, that is, a person that has gender equality responsibilities. The length of the interviews depended on the policy actors' commitment and interest in the collaboration projects. The shortest interviews lasted 10 minutes and the longest interviews lasted up to 30 minutes. The interviews were digitally recorded and transcribed using qualitative methods. To ensure the confidentiality and anonymity of the participants, at once challenging and important in a small community like Iceland, we decided to only describe the interviews using the previously mentioned classification method. Therefore, we only occasionally distinguish between the City and the University in the thematic discussion.

The interview data were analysed according to the thematic analysis, which is consistent with the systematic phases of the grounded theory approach (Glaser and Strauss) with the assistance of Atlas.ti. The first author coded the data using an inductive approach to identify meaningful dimensions in the data. The author's experience, especially scholarly, influences the assignment of codes (such as Bacchi and Eveline on the project trap and Andersson on the question of feminism being present or absent in gender mainstreaming). In the first step of the analysis, 13 codes were identified. In the second step, which aimed to clarify the complexity of the findings in a more fitting manner, the authors reorganised the codes into three themes in the final phase of the analysis: Organisational noncommitment, inadequate knowledge and superficial approach. Organisational noncommitment included the codes: reject responsibility, not taking action, aura of gender equality and indifference. Inadequate knowledge included the codes: lack of knowledge and feminism excluded. Superficial approach included the codes: embrace responsibility, perceived important, evidence of practice, feminism present, superficial implementation, creating knowledge and lack of resources. In the next 
section, we present the findings from the analysis by the themes identified. Firstly, we discuss the organisational commitment to gender mainstreaming and gender budgeting. We then discuss the policy actors' understanding of and knowledge about the strategies and how they approach the implementation of the strategies.

\section{ORGANISATIONAL NONCOMMITMENT}

Equality, gender mainstreaming and gender budgeting are concepts that the policy actors accepted and frequently used. However, organisational noncommitment also exists because most of the interviewed policy actors do not apply these strategies in their work. The reasons for this include: implementation of gender-related strategies are a low priority, they are dependent on individuals taking action, they receive little support, there is an «aura of gender equality» (Pétursdóttir 3) in the organisation and there is a lack of gender+ awareness.

The interviews allowed us to delve into the paradox of «strong equality policy, weak practice» (Johnson, Einarsdóttir and Pétursdóttir 175). Despite the existence of gender equality machinery and the formal adoption of gender mainstreaming and gender budgeting within the organisations, as discussed above, the participants often disregard the responsibility for the gender mainstreaming processes. Furthermore, it was not clear to them who should have that responsibility. Only four of the 11 policy actors perceived the strategies, including an intersectional perspective, to be part of their job. One mid-level policy actor had never heard of the strategies, nor the City's responsibilities according to the law, even though her division and her tasks were part of the collaboration projects. This is in line with Benschop and Verloo's (284) warning that the implementation of gender mainstreaming will fail if all the organisational actors are expected to enact gender mainstreaming. Another mid-level policy actor stressed that the organisation needs to clarify the staff's responsibilities towards equality issues and establish a clear action plan if it is serious about implementing the strategies: «I think that, generally, people do not perceive working on gender equality as a part of their job».

In cases were equality issues are on the agenda, they seem to be low in terms of the organisation's priorities, as can be seen in this response from a 
mid-level policy actor: «Many people see [equality] as a pet project; therefore, they [the equality projects] usually go to the bottom of the list [of priorities]».

Similar to Scala and Paterson's (230) findings, according to some of the policy actors that were interviewed, the progress of equality issues depends on the interest and endurance of the individual policy actor and the support of their superiors and colleagues. Some policy actors described how the lack of interest in and discussion about these issues can be a significant hindrance to equality work. Attitudes within their division, especially men's approval, is a lever for equality work. This can be seen in the statement below, in which a mid-level policy actor at the University gives credit to her male colleagues for the (alleged) success of the workplace with gender mainstreaming: «We have, thankfully, a few male feminists within our unit that are conscious. So, [application of gender mainstreaming] has proven to be easy for us».

The need for men's gender awareness and support for progress echoes previous accounts of the conflict around gender equality work (Andersson 203). Moreover, it reflects the gendered power relations within the workplace; without support from men, no progress will be made.

The aura of gender equality, in other words the perception of gender equality despite practical evidence indicating otherwise (Pétursdóttir 3), was evident among the responses of some of the policy actors. They perceived themselves and their workplaces to be working hard to realise gender equality and that they had mainstreamed gender into their policies and decision-making processes. However, the lack of evidence of practice demonstrates how the transformative aspect of the strategies can easily fail to materialise (Benschop and Verloo 284). For example, as seen in the comment below, a management policy actor at the University not only exaggerates the proportion of the academic staff that have gender expertise, but also believes that having a gender perspective in some of the research activity within the school automatically results in gender and equality perspective being present in the school's policies and decision-making process: «I think that at least one-third of the staff are in some way experts in equality issues, especially gender equality, so it impacts all their work whether it being administration or teaching».

Closely related is the lack of gender+ awareness and the perception that all individuals are equal; thus, meeting the needs of different groups is seen 
as discrimination. A management policy actor who provides services directly to students at the University noted:

[Gender and diversity] are definitely not a perspective that we have been systematically incorporating because we are somehow just looking at the group of students. Gender doesn't matter, and it just, we just want to service the students and period. You know, that is the way it is.

This individualistic approach is also apparent at the City. A collaboration project revealed a gendered patter in how people sought services, that is men sought information on «masculine» issues and women on «feminine» issues, and that marginalised people, such as foreigners and disabled people, used the services to a very small extent. However, when a management policy actor was asked if her division has taken any measures to reach different groups of citizens with their services, she responded as if everyone had the same needs: «Everybody gets the same service. Everybody. It is our motto that everybody gets the same service. There is no one that gets more service than the other, or more or less service».

Bacchi and Eveline («Approaches» 131) warn against approaching the problem in a narrow context, that is, by focusing on individuals and leaving out broader gender and social relations. The lack of understanding about gender and social relations and how they can be reproduced in the decision-making process is linked to inadequate knowledge. This is discussed in the next section.

\section{INADEQUATE KNOWLEDGE}

Two of the policy actors interviewed had an educational background in gender studies, and they have a clear vision and understanding of the application of gender mainstreaming and gender budgeting, both in general and within their field of work. Their knowledge of gender theory influences their approach, which includes a feminist perspective, as can be seen in the comments from a policy actor from the City:

[Gender budgeting] is a strategy that the City, as an authority, is using to facilitate equality. That is the point. However, I think too often the very objective gets left behind, that is, that we are doing this because of inequality, and we are trying 
to change that. And I think it is an important reminder that the precondition for doing [gender budgeting] is acknowledging that there is inequality.

The policy actor criticises the focus on an increasingly bureaucratized process, and stresses that policy actors need to remember that the purpose of gender budgeting is transformative. Apart from these two policy actors, there is a general lack of knowledge on gender mainstreaming and gender budgeting, that reflects Woodward's (69) observations about the risk of gender mainstreaming being compromised when applied by non-femocrats. When asked if they had taken any measures to correct the representation of diverse groups in their public facing communication material, a mid-level policy actor with a gender background ponders if a lack of knowledge about and understanding of how to include the gender and diversity perspective should be expected:

I wonder what we can expect from the staff, even though we are all very bright here [in this division]. But if you consider it in general, that everybody must have a clear understanding. Because I sometimes feel that it isn't even clear in the literature. We must have it well defined.

The lack of knowledge among policy actors can be manifested in their perspective that gender mainstreaming and gender budgeting: a) cannot be applied to the particular services provided by the City or the University, nor can they be applied to their particular area of work; and b) are (only) accomplished through equal gender representation and equal pay.

The general understanding that gender mainstreaming and gender budgeting cannot be applied to all the services provided by the City and the University stems from the general lack of knowledge about how public policy and public spending and revenue can maintain and even produce inequalities -that is, the policies can be inherently gendering and heteronorming, racializing, classing and (dis)abling (Bacchi and Eveline, «Approaches» 112). The comments below from a management policy actor from a service-focused division at the City stand out as she sees gender and other social and power relations as important factors because of the obligation of equity in public administration. According to her, all decisions are built on assessments of the need for and use of services and monthly monitoring:

We assess if the services [provided by the City] are in accordance with regulations and procedures, and of course we must include an equality perspective, 
whether it is gender equality or other equality perspectives. So, we are constantly assessing if the services are consistent with if you are a man or a woman, poor or rich, because everybody is supposed to have access to the same services. [...] Our procedures must ensure equity.

Other policy actors disconnected the gender equality perspective from the policy and the spending and revenue; hence, gender is not mainstreamed into their decision-making processes. This is seen in the comments made by a management policy actor: «Well, [gender budgeting] is more like a project, because the day-to-day tasks are more focused on the operation, the finances and the services».

The disconnection between the gender+ perspective, finances and the decision-making process can be reflected in the assumption that decision-making is gender neutral (Bacchi and Eveline, «Mainstreaming» 52; O'Hagan and Klatzer 5). The perceived gender neutrality of decision-making, such as providing services to citizens or students, maintains the idea that gender mainstreaming is a separate task or project. The «project trap» (Bacchi and Eveline, «Mainstreaming» 52) can be reflected in the words of a management policy actor:

[Gender mainstreaming] is not exactly one of my tasks, simply because we are first and foremost here to provide services to citizens. But of course, I spend a lot of time each month thinking how I can even the gender balance within the workplace.

This management policy actor sheds a light on a common misunderstanding, held by half of the participants, that gender mainstreaming and gender budgeting mean equal pay or encouraging equal representation of men and women employed in the workplace and participating in decision-making processes. This can be seen in the comments made by another management policy actor at the University, whose division has participated in a number of collaboration projects on organisational issues that revealed gendering practices, e.g. in terms of workloads for student supervision, internal support grants for teaching assistance and the position of the PhD students. When asked if gender perspectives are included in his division's policy-making efforts, he said: «Yes. Well, only to the extent that we make sure that there is equal gender representation in the decision-making processes». 
The idea that gender mainstreaming is simply counting bodies is widespread among the policy actors, despite their participation in the collaboration projects, and despite the fact that gender mainstreaming has been obligatory since 2008 (Act on the Equal Status and Equal Rights of Women and Men no. 10/2008) and gender budgeting has been on the agenda since 2010 at the City and 2013 at the University (Steinpórsdóttir et al. 179). Even though gender representation is an important aspect of gender equality, it is not enough to eliminate gender biases in decision making (see e.g. Stainback, Kleiner, and Skaggs 130; Childs and Krook 145). The same can be said about equality policies. Having a gender equality policy is often considered to be gender mainstreaming, as seen in the comments from a management policy actor when asked if gender and diversity are mainstreamed in their decision-making process:

Well yes, we have a special equality or policy against discrimination or whatever. It was of course the integration of the equality policy and a policy on other discrimination, and of course [a feminist] lead the work.

This management policy actor reveals his lack of knowledge about gender mainstreaming, and his comment about a gender expert being on board appears to be an alibi. This approach -having an equality policy but not taking any action- is unlikely to result in transformative action.

However, one mid-level policy actor is aware of these problems, and she emphasised the need to increase awareness among financial directors and other policy actors to facilitate the implementation of gender budgeting:

I believe that training is part of the implementation. The aim of the training is to make people aware that the reason we are doing this is to facilitate equality and it is our responsibility. Also, The City, as a workplace and as an authority, is working towards facilitating equality. Because that is something we want to do. Always. And that it becomes part of people's consciousness.

\section{SUPERFICIAL APPROACH}

Our findings substantiate findings from the literature on the implementation gap (e.g. Bendl and Schmidt 375; Bacchi and Eveline, «Mainstreaming» 52; O'Hagan and Klatzer 7; Scala and Paterson 208; Sharp and Broomhill 21). There are few signs of gender being mainstreamed systematically into the 
policy actors' decision-making processes. In general, the approaches of the policy actors that considered themselves to be implementing gender mainstreaming and gender budgeting were superficial. This includes a) confusing the «awareness» of inequality and performing a gender impact assessment with implementation of the strategies; and b) taking no action, which maintains the social and political status quo.

The objective of gender mainstreaming and gender budgeting is commonly understood simply to be the production of knowledge about the gender+ dimensions of society or specific activities. In general, most of the policy actors believed that a gender+ impact assessment, as well as the outcome of the collaboration projects, represented the full implementation of the strategies. This can be seen in the comments made by a management policy actor from the City when discussing the outcomes of a project on participation in services provided by the senior community centre, revealing the need to encourage men's participation: «I think the main goal is that [the collaboration project] gave us something to think about. And that is a very big step».

When the policy actors were asked about how they apply the strategies in their work, awareness of inequality (e.g. they «should be thinking about» and "should always be checking» the gender perspective) was a common reference point. However, as a management policy actor noted, this approach tends to omit gender issues from the agenda: «I should always think about [gender]. I am not sure I have always done that, but I try. But I need to be reminded about [including that perspective]».

Contrary to Sharp and Broomhill's (8) suggestions that critical engagement with external actors could facilitate implementation, the policy actors did not demonstrate accountability for correcting or responding to the gendering processes and outcomes of the gender+ impact assessments. Gender biases are seen as something that one needs to be aware of or forwarded to some other accountable unit. They are not necessarily something to be acted on by oneself or to be addressed as a matter of institutional or strategic importance. This belief is seen in the comments made by a University management policy actor when asked about action taken following collaboration projects revealing gender stereotypical committee representation and lack of diversity in their promotion material: «[The findings] are useful and need to be delivered 
to the Equal Rights Committee. Not that the committee must act on it, more just to keep us aware [of the problems]».

It is common that the policy actors that have accountability refer the findings of a gender impact assessment to committees without this resulting in further action. One of the mid-level policy actors participating in a project on internal grants revealing gender imbalances in favour of men criticised:

I remember one example. We got this good report, an assessment of funds, and it was not possible to get a decision [on how to react to its findings] from the committee. [They should have] sent the recommendations to the governing bodies of the funds to do something about the applications system, the decisions, because these were the issues referred to [in the report]. This was wiped off the table. And I said: Why are we doing these projects and not using the findings for improvement? I don't know if they have done anything.

When the policy actors discussed evidence of practice to correct imbalances or biases, their approach usually disregarded gendered power relations. They approached the problem in gender-neutral terms; that is, the aim was to even out differences between women and men rather than looking at the factors that produce those differences. Action is taken when the service is believed to be biased against men, reflecting a narrow approach to the problem and ignoring the power and social relations (Bacchi and Eveline, «Mainstreaming» 52). Two examples illustrate this «project trap», both from management policy actors who have been overly focusing on balancing the gender representation within their female-dominated fields (that is, increasing the number of men). One policy actor works in administration at the University and the other works in elderly care for the City. This shows how men are prioritised in gender equality work, and it demonstrates a lack of understanding of gendered power relations.

When asked about how she works towards equality, a management policy officer replied that she gives all the staff at her division, men and women, permission to leave during the Women's Day Off, which is the Icelandic Women's strike for equal pay (Kvennafrí). Since the policy officer could not refer to any other evidence of practice, this insinuates that this action is symbolic, being used as an alibi. Moreover, giving both women and men a day off depoliticises the strike, which aims to demonstrate how society and workplaces would not 
function without women's under-recognised contribution -and it reflects the tendency to avoid conflict in gender equality work (Andersson 203).

According to a mid-level policy actor, the collaboration projects are important in order to counteract the gender-neutral approach, and they take into account gendered power relations in a gender impact assessment and when implementing gender mainstreaming and gender budgeting:

When we are collaborating with the students, they are assessing things that we often do not see. And yes, I believe they create good knowledge. What is more, I think we do not necessarily look critically at what we are doing. We do not often take a step back and look at the whole picture, or look at it from a different perspective, and that is why I believe it is very good to get these students' projects.

Not all the policy actors were as positive; there were many times when the policy actors had not even looked into the findings from the collaboration projects or had forgotten about them. None of the cases of students' collaboration projects resulted in action being taken despite the findings from a gender impact assessment of a policy or if a decision revealed gender imbalances and biases. Hence, despite the engagement of external actors, the projects did not result in chains of accountability, as suggested by Sharp and Broomhill (22). Some policy actors said the lack of resources, such as time, staff and money, hinders them from doing any reform work. However, the lack of action sometimes stems from indifference, as seen in the response of a management policy actor who participated in projects on internal grants and academic housework (Heijstra et al. 211): «Well, no. Our feeling is that our system is rather good». In this instance, he relied more on his own intuition about the system rather than evidence of the outcome of the project, which would require correction of gendered imbalances and biases.

Many policy actors find it difficult to respond to gender biases because they do not perceive themselves as having the power to make decisions and change the processes to ensure more equal outcomes. There were contradictions in the discussions about taking action at the University. Many of the policy actors said the mandate must come from the central administration and the top management at the University. At the same time, the policy actors from the central administration claimed that they do not have any power over the policy and the decision-making process at lower organisational levels. Even high-ranking policy actors talked about the lack of a mandate 
to take action towards ensuring more equal outcomes. This is interesting because, as previously mentioned, equality is a well-recognised policy goal at the University. These perspectives about taking action indicate that these policies are essentially window dressing. Thus, there is a general reluctance to take responsibility for equality issues. This perspective further undermines the resolve towards the possibility of taking action, as seen in the comments from a mid-level policy actor who participated in the public relation projects: «We have a rather big set-up, so it is difficult to steer some issues and... yeah, just impossible».

\section{DISCUSSION AND CONCLUSION}

The objective of this research was to study how organisations respond to public policy and legislation on gender mainstreaming and gender budgeting. We studied the outcomes of implementation projects performed within two organisations, the City and the University, in collaboration with the Department of Gender Studies at the University. Drawing on the findings, in this section we discuss the potential for and hindrances of using such collaboration projects to jumpstart transformative gender+ equality work within organisations.

The national legislation and organisational policies require organisations to integrate gender into all their policies and decision-making processes. However, as seen from the interviews with the policy actors, there is little indication that gender mainstreaming and gender budgeting are being fully delivered within the City and the University. This is in line with Bacchi and Eveline's (306-307) findings that organisational obligation does not necessarily lead to organisational commitment. Assessing the status of the implementation of the strategies from the technocratic perspective, the policy actors interviewed revealed that if they apply the strategy, they do not go beyond the gender analysis of specific activities. In general, gender analysis is not integrated into their policies and decision-making processes. In terms of the collaboration projects, the students performed the analysis and provided research-informed advice on how to integrate the gender perspective into decisions on the activity in question. However, similar to Andersson (215216), actions that could improve gendering policies, decisions or processes 
are avoided. Moreover, there is hardly any evidence that the policy actors had taken action to improve the position of women. Hence, at best, the collaboration projects managed generate knowledge about the alleged gender-neutral activity. This almost always only resulted in knowledge production for the policy actor in question, as most of the findings and suggestions from the collaboration projects were not presented to other members of the organisation. Moreover, the gender analysis findings and the research-informed advice produced in the collaboration projects rarely led to transformation of organisational processes to ensure more gender equal outcomes, which is the objective of gender mainstreaming and gender budgeting (Benschop and Verloo 283; O'Hagan 20-21).

Legislation and policies, as well the theoretical idea of gender mainstreaming, make all the policy actors responsible for mainstreaming gender into all policies and decision-making processes. Benschop and Verloo (284) voice concerns about this approach because of the misunderstanding about gender and gender mainstreaming among the policy actors. Our findings support this lack of understanding of the problem and of the gender perspective was common among the policy actors. Some of them remained in the aura of gender equality (Pétursdóttir 3) and had difficulties seeing the relevance of gender (Eveline and Bacchi 306-308). They had a tendency to fall into the project trap, and in their approaches they overlooked the social and power relations that have been identified as central in other literature (Bacchi and Eveline, «Mainstreaming» 52; O'Hagan and Klatzer 5). One example of the project trap was when policy actors approached the service users (students or citizens) in gender-neutral terms, superficially aiming to even out the differences between men and women. In line with Andersson (2015), approaching the issues from a feminist perspective was not seen as legitimate or professional (Andersson 215). Nonetheless the policy actors who had an understanding of gender and other social relations approached their work from a feminist perspective and tried to challenge and change the gendering processes. However, their power to transform the system is limited. This confirms Benschop and Verloo's concerns (284) that by making the strategy everyone's responsibility can result in the strategy failing all together.

The focus on management and mid-level policy actors within the organisations rather than high-level management, is both a strength and a limitation 
of our study. It is a strength, because it reveals the understanding and perspectives that the policy actors, who are regularly involved in implementation, have about gender mainstreaming and gender budgeting. This is an aspect that has not received much attention in the literature (Scala and Paterson 209). It is a limitation because the systematic implementation of the strategies might be done elsewhere in the organisations but these policy actors might not be aware of it. Hence, we suggest that future research conducts a more comprehensive assessment of the status of the implementation within organisations. The findings of our study suggest that implementation of gender mainstreaming and gender budgeting processes and procedures are lacking in the organisations under study, echoing the established perspectives in the literature in relation to this problem. Consequently, the equality infrastructures need to be strengthened with formal authority and resources, and gender mainstreaming and gender budgeting processes and procedures must be formalised (Klatzer, Brait, and Schlager 152; Benschop and Verloo 284-287; Eveline and Todd 551-554).

The collaboration projects clearly reveal the weaknesses and the shortcomings of gender+ equality work. However, if we can overcome certain hindrances, we believe collaboration projects on gender mainstreaming and gender budgeting have the potential to facilitate change. To increase the organisational commitment, the policy actors need to be more involved in the collaboration projects, as suggested by Eveline and Bacchi (306-308). In other words, the policy actors need to be given more hands-on experience conducting gender analysis, so they can see how the problems are created. Learning by doing will enhance the policy actors' knowledge about and understanding of the problem and the gender+ perspective.

Presenting and sharing project outcomes within the organisations increase the likelihood that the knowledge production will benefit other policy actors within the organisations and would also increase awareness of the gendering of the policy and decision-making processes. Chains of accountability need to be established. This could be done by making the students' reports publicly available. These reports could be employed by external actors, such as feminist advocates, that might be excluded from the implementation processes (Powell, Ah-King and Hussénius 129; Klatzer, Brait and Schlager 147-151), to hold the organisations accountable. 
Gender analysis is important, but in order for the implementation to be successful, organisations must make the effort to take action and change their organisational processes to promote the production of equality (O'Hagan 20; Benschop and Verloo 283; Bendl and Schmidt 364; Eveline and Todd 537). To support the policy actors in taking action to implement gender mainstreaming and gender budgeting, the collaboration has to be extended beyond the collaboration projects. This could be done with follow-up support from the experts at the Department of Gender Studies. More follow-up support on the collaboration projects is likely to result in positive outcomes, or small wins, in line with Correll's model, which has the potential to motivate further action (Correll 735-737). This will reinforce the idea that the strategy needs to be an ongoing process of analysis and re-visioning (Eveline and Todd 551-554). Resources, which are often lacking, are most likely needed for that support to be realised. However, in the literature, it is well-documented that organisations benefit from collaboration with gender experts and research (Benschop and Verloo 284-287; Eveline and Todd 551-554).

In this article, we explored the collaboration projects between students in the Department of Gender Studies and policy actors at the University and the City. The collaboration projects are based on the idea of a jumpstart along with a «small wins» model of change. Identifying the potentials for and the hindrances of the collaboration projects has generated knowledge about the conditions required to fully jumpstart and implement structural transformative gender+ equality work.

\section{REFERENCES}

Act on Equal Status and Equal Rights of Women and Men No. 10/2008 (Icel.).

Andersson, Renée. «The Question of Feminism in Gender Mainstreaming -a

Case of Non-Conflict in Local Politics». NORA-Nordic Journal of Feminist and Gender Research 23.3 (2015): 203-19.

Bacchi, Carol. Analysing Policy: What's the Problem Represented to Be? Frenchs Forest, N.S.W.: Pearson, 2009.

Bacchi, Carol, and Joan Eveline. «Mainstreaming and Neoliberalism: A Contested Relationship». In Mainstreaming Politics: Gendering Practices and Feminist Theory. Eds. Carol Bacchi, and Joan Eveline. Adelaide: University of Adelaide Press, 2010. 39-60.

Feminismo/s 35, junio 2020, pp. 179-205 
Bacchi, Carol, and Joan Eveline. «Approaches to Gender Mainstreaming: What's the Problem Represented to Be?». In Mainstreaming Politics: Gendering Practices and Feminist Theory. Eds. Carol Bacchi, and Joan Eveline. Adelaide: University of Adelaide Press, 2010. 111-38.

Bendl, Regine, and Angelika Schmidt. «Gender Mainstreaming: An Assessment of Its Conceptual Value for Gender Equality». Gender, Work \& Organization 20.4 (2013): 364-81.

Benschop, Yvonne, and Mieke Verloo. «Gender Change, Organizational Change, and Gender Equality Strategies». In Handbook of gender, work and organization. Eds. Emma Jeanes, Daid Knights, and Patricia Yancey Martin. West Sussex: Wiley, 2011. 277-90.

Charmaz, Kathy. Constructing Grounded Theory: A Practical Guide through Qualitative Analysis. London: Sage Publications, 2006.

Childs, Sarah, and Mona L. Krook. «Analysing Women's Substantive Representation: From Critical Mass to Critical Actors». Government and Opposition 44.2 (2009): 125-145.

Correll, Shelley J. «Sws 2016 Feminist Lecture: Reducing Gender Biases in Modern Workplaces: A Small Wins Approach to Organizational Change». Gender E Society 31.6 (2017): 725-50.

Council of Europe. Gender Mainstreaming: Conceptual Framework, Methodology and Presentation of Good Practices. Final Report of Activities of the Group of Specialists on Mainstreaming. Strasbourg: Directorate General of Human Rights, 1998.

Council of Europe. Recommendation 1921. Strasbourg: Council of Europe, 2010. Einarsdóttir, Porgerður. «All that Glitters is Not Gold: Shrinking and Bending Gender Equality in Rankings and Nation Branding». NORA - Nordic Journal of Feminist and Gender Research (2020): 1-13.

Einarsdóttir, Porgerður, and Gyða M. Pétursdóttir. «Meðbyr og ágjöf: próun kynjafræðináms í íslensku samhengi». Íslenska pjóðfélagið 10.3 (2019): 5-29.

Eveline, Joan, and Carol Bacchi. «Obeying Organisational 'Rules of Relevance': Gender Analysis of Policy». In Mainstreaming Politics: Gendering Practices and Feminist Theory. Eds. Carol Bacchi and Joan Eveline. Adelaide: University of Adelaide Press, 2010. 283-310.

Eveline, Joan, and Patricia Todd. «Gender Mainstreaming: The Answer to the Gender Pay Gap?». Gender, Work E Organization 16.5 (2009): 536-58. 
Glaser, Barney, and Anselm Strauss. The Discovery of Grounded Theory: Strategies for Qualitative Research. New York: Aldine, 1967.

Háskóli Íslands. Equality and Diversity. 25 January 2020. <https://english.hi.is/ equality>

Háskóli Íslands. University of Iceland Equality Action Plan 2018-2020, 2018. <http://english.hi.is/university/equal_rights_policy>

Heijstra, Thamar M., Porgerður Einarsdóttir, Gyða M. Pétursdóttir, and Finnborg S. Steinpórsdóttir. «Testing the concept of academic housework in a European setting: Part of academic career-making or gendered barrier to the top?». European Educational Research Journal 16.2-3 (2017): 200-214.

Her Majesty the Queen in Right of Canada. Gender report. Budget 2019. 19 May 2020. <https://www.budget.gc.ca/2019/docs/gba-acs/gbs-acs-en.pdf>

Johnson, Janet, Porgerður Einarsdóttir, and Gyða Margrét Pétursdóttir. «A Feminist Theory of Corruption: Lessons from Iceland». Politics E Gender 9.2 (2013): 174-206.

Keisu, Britt-Inger, Lena Abrahamsson, and Malin Rönnblom. «Entrepreneurship and Gender Equality in Academia -a Complex Combination in Practice». Nordic Journal of Working Life Studies 5.1 (2015): 69-92.

Klatzer, Elisabeth, Romana Brait, and Christa Schlager. «The Case of Austria: Reflections on Strengthening the Potential of Gender Budgeting for Substantial Change». In Gender Budgeting in Europe: Developments and Progress. Eds. Angela O'Hagan and Elisabeth Klatzer. New York, London: Palgrave Macmillan, 2018. 137-157.

Kvennafrí. Kvennafrí. 26 January 2020. <https://kvennafri.is/en/front1-en/> Lombardo, Emanuela, and Lut Mergaert. «Gender mainstreaming and resistance to gender training: A framework for studying implementation». NORA-Nordic Journal of Feminist and Gender Research 21.4 (2013): 296-311.

Mackay, Fiona, Surya Monro, and Georgina Waylen. «The Feminist Potential of Sociological Institutionalism». Politics E Gender 5.2 (2009): 253-262.

O'Hagan, Angela. «Conceptual and Institutional Origins of Gender Budgeting». In Gender Budgeting in Europe: Developments and Progress. Eds. Angela O'Hagan and Elisabeth Klatzer. New York, London: Palgrave Macmillan, 2018. 19-42.

O'Hagan, Angela, and Elisabeth Klatzer. «Introducing Gender Budgeting in Europe». In Gender Budgeting in Europe: Developments and Challenges. Eds. Angela O'Hagan and Elisabeth Klatzer. New York, London: Palgrave Macmillan, 2018. 3-19.

Feminismo/s 35, junio 2020, pp. 179-205 
Pétursdóttir, Gyða Margrét. Within the Aura of Gender Equality: Icelandic Work Cultures, Gender Relations and Family Responsibility. A Holistic Approach. Diss. University of Iceland, 2009.

Powell, Stina, Malin Ah-King, and Anita Hussénius. «'Are We to Become a Gender University?' Facets of Resistance to a Gender Equality Project». Gender, Work E Organization 25.2 (2018): 127-43.

Reykjavíkurborg. Mannréttindi [Human Rights]. 25 January 2020. <https://reykjavik.is/mannrettindin>

Reykjavíkurborg. Kynjajafnrétti [Gender Equality]. 25 January 2020. <https:// reykjavik.is/jafnretti-1>

Reykjavíkurborg. Human Rights Office. 25 January 2020. <https://reykjavik.is/ city-reykjavik-human-rights-office>

Scala, Francesca, and Stephanie Paterson. «Stories from the front lines: making sense of gender mainstreaming in Canada». Politics \& Gender 14.2 (2018): 208-234.

Sharp, Rhonda, and Ray Broomhill. A case study of gender-responsive budgeting in Australia. London: Commonwealth Secretariat, 2013.

Stainback, Kevin, Sibyl Kleiner, and Sheryl Skaggs. «Women in Power: Undoing or Redoing the Gendered Organization?». Gender E Society 30.1 (2016): 109-35.

Steinpórsdóttir, Finnborg S., Katrín Anna Guðmundsdóttir, Thamar Melanie Heijstra, and Halldóra Friðjónsdóttir. «Gender Budgeting in Iceland». In Gender Budgeting in Europe: Developments and Challenges. Eds. Angela O'Hagan and Elisabeth Klatzer. New York, London: Palgrave Macmillan, 2018. 179-98.

Verloo, Mieke, and the Quing consortium. Final Quing Report. Vienna: Institute for Human Sciences, 2011. <https://www.iwm.at/projects/quing/www.quing. eu/files/QUING_Final_Report_Jan\%2012.pdf>

Woodward, Alison. «European Gender Mainstreaming: Promises and Pitfalls of Transformative Policy». Review of Policy Research 20.1 (2003): 65-88.

World Economic Forum. The global gender gap report. Geneva: WEF, 2020. 